\title{
English students' experience of reframing narrative stories from a critical literacy perspective
}

\author{
Gin Gin Gustine* and Hikmah Nur Insani \\ Department of English Education, Faculty of Language and Literature Education, Universitas Pendidikan Indonesia, \\ Jl. Dr. Setiabudhi, No. 229 Bandung, West Java, Indonesia
}

\begin{tabular}{|c|c|}
\hline $\begin{array}{l}\text { ABSTRACT } \\
\text { This article reports a study investigating the Engli } \\
\text { secondary school students of English to be critically lit } \\
\text { texts. In this study, Luke and Freebody's (1999) four re } \\
\text { used as a framework for English instruction situated in } \\
\text { were collected from classroom observations, students' } \\
\text { with secondary school students. The findings showed th } \\
\text { literacy, to some extent, helped students to become crit } \\
\text { meaning-making-of and criticizing the text. The implic } \\
\text { possibility of implementing critical literacy-oriented } \\
\text { Asian secondary schools. }\end{array}$ & $\begin{array}{l}\text { cher's strategies for assisting } \\
\text { hrough an analysis of narrative } \\
\text { es model of critical literacy was } \\
\text { onesian secondary school. Data } \\
\text { tive journals, and an interview } \\
\text { four resources model of critical } \\
\text { iterate especially at the stage of } \\
\text { of the study is that there is the } \\
\text { classrooms in Indonesian and }\end{array}$ \\
\hline Keywords: Critical literacy; narrative texts; secondary & the four resources model \\
\hline $\begin{array}{l}\text { First Received: } \\
\text { 19 March } 2018 \\
\text { Final Proof Received: } \\
\text { 25 January } 2019\end{array}$ & $\begin{array}{l}\text { Accepted: } \\
\text { 22 November } 2018 \\
\text { Published: } \\
\text { 31 January 2019 }\end{array}$ \\
\hline $\begin{array}{l}\text { How to cite (in APA style): } \\
\text { Gustine, G. G., \& Insani, H. N. (2019). English students } \\
\text { stories from a critical literacy perspective. Indonesi } \\
\text { 691-696. doi: } 10.17509 / \mathrm{ijal} . \mathrm{v} 8 \mathrm{i} 3.15254\end{array}$ & $\begin{array}{l}\text { nce of reframing narrative } \\
\text { nal of Applied Linguistics, } 8\end{array}$ \\
\hline
\end{tabular}

\section{INTRODUCTION}

Critical literacy has long been established as an alternative approach to teaching English, especially in English-speaking countries. However, in English as a Foreign Language (EFL) settings, especially in the Indonesian context, the notion of critical literacy as an approach to teaching English is under-practiced in both secondary education and tertiary education (Gustine, 2018; Tungka, 2018). Against this backdrop, critical literacy gains its importance in our everyday life (Janks, 2014), especially in the current Indonesian education context where the Indonesian Ministry of Education mandates teachers to include principles of critical literacy in their school subjects. In this respect, schools that have implemented the revised 2013 curriculum (see Widodo, 2016b) are required to incorporate higherorder-thinking skills (e.g., features of critical literacy) into school subjects.

In other words, the current mandated educational policy and curriculum challenge teachers to design critical literacy-oriented classrooms. For this reason, teachers have to be ready for creating a more critical classroom atmosphere (Gustine, 2018). In line with this, previous research on critical literacy in Asian EFL contexts has also indicated that teachers play an important role in assisting their students to be critically literate (Fajardo, 2016; Huh, 2016; Kim, 2016; Ko, 2010; Tungka, 2018; Widodo, 2016a). To meet this need, this article reports empirical evidence that showcases English teacher's strategies for helping secondary school students reframe narrative texts from a critical literacy perspective.

The model of critical literacy adopted in this study is the four resources model developed by Luke and Freebody (1999). This model is helpful for language teachers to assist learners in decoding, understanding, using, and critiquing texts. Thus, it is considered as the most influential model that can be adopted in the language classroom (Larson \& Marsh, 2005). The Luke and Freebody's (1999) four resources model complements Green and Beavis' (2013) 3D model of literacy and the four dimensions model of critical

\footnotetext{
* Corresponding Author

Email: gustine@upi.edu
} 
literacy suggested by Lewinson, Leland, and Harste (2015) which view literacy as a sociocultural practice and brings together the literacy dimensions of operational/language, the cultural meaning and the critical power. Thus, grounded on the four resources model of critical literacy in this article, language teachers play a pivotal role in assisting learners in using language to problematize the everyday world and investigate how a power relationship is socially constructed.

\section{THE STUDY}

Grounded in practitioner research, both of the authors acted as researchers and practitioners who implemented the four resources model of critical literacy in an English language classroom. The site of the study was a private secondary school in Indonesia in which 18 students (Year 8) were recruited as participants by using convenience sampling. For pedagogical resources, the narrative texts used in the designed critical literacybased English classroom included five fables stories in which animals were the main characters of the stories. The fable stories as main texts were used because as stipulated in the current English language curriculum (see Widodo, 2016b), a narrative is one of the genres that English teachers have to teach to second-year (Year 8) students. Thus, short stories belong to narrative texts. For this reason, the authors selected the following stories: The Rabbit and The Turtle; The Bear and The Two Friends; Two Cats and The Monkey; The Ugly Duckling; and The Father, The Son, and The Donkey. These stories were chosen as they contain moral values which may raise students' moral awareness of texts. For example, such moral themes as friendship, familyrelated conflicts, and self-esteem are part of character education as stipulated in the current English language curriculum (see Widodo, 2018).

Data were garnered from classroom observations, a focus group interview, and students' written responses (reflective journals). The authors conducted multiple observations (seven class periods) to avoid observer's paradox (see Widodo, 2016a) in which each classroom observation lasted seventy minutes. The artefacts of the classroom observations in this study were video recordings and the researchers' field notes. The focus group interview was conducted to gain more data that could empirically support to classroom observation data. Students' reflective journals took the form of individual and group responses to questions related to the teaching and learning process. The verbatim data were analysed by using the four resources model developed by Luke and Freebody (1999).

\section{FINDINGS AND DISCUSSION: REFRAMING NARRATIVE STORIES FROM A CRITICAL LITERACY PERSPECTIVE}

This section presents the findings and discussion drawing from the data obtained during the field work. Grounded in the principles of the four resources model, the findings and discussion are structured based on four critical literacy circles: (1) breaking the code of text, (2) participating in making meaning, (3) using text functionally and purposely, and (4) critically analyzing the text (Luke \& Freebody, 1999).

\section{Breaking the code of text}

At this stage, as suggested by Luke and Freebody (1999), students were encouraged to be a code breaker responsible for comprehending some basic features of text which involve alphabets, sounds, punctuations, sentence patterns, and word formation. This fundamental stage also emphasized decoding and encoding the codes. It means that the students had to identify and respond to some questions to break the code in the narrative text given. Moreover, the students were encouraged to find out some background elements of the narrative text. They went through four codecracking stages: (1) vocabulary recognition, (2) basic information about the narrative stories (3) visual codes, and (4) non-verbal codes.

First, the vocabulary recognition encouraged the students to identify some difficult words gleaned from each narrative text. For example, several students did not know the meaning of words "boasting" and "umpire" in the story of The Rabbit and the Turtle. It can be seen in Excerpt 1 below. $T$ is the teacher, and D is Dita, one of the students. To conform to research ethics, all participants' names are written in pseudonyms.

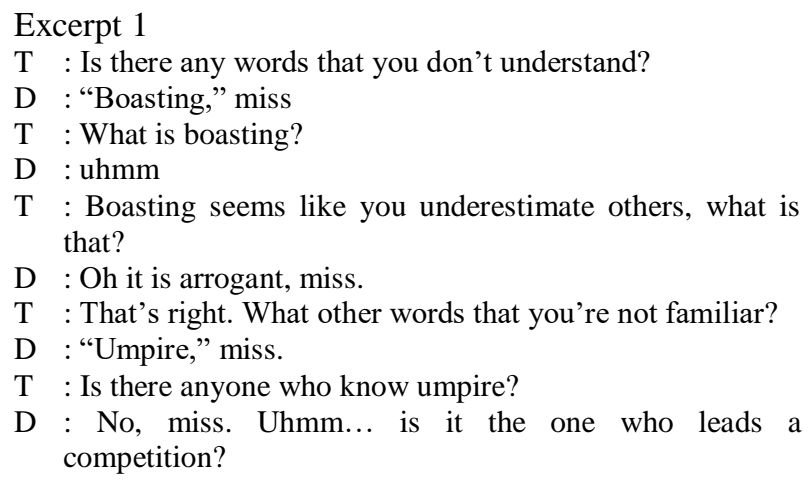

From this excerpt, Dita seemed to be able to crack the code and recognize the meaning of the word "arrogant" and elaborate its meaning. In addition, the process of vocabulary recognition also happened in the word "umpire." Dita was unsure of the meaning of umpire in the beginning, but she tried to guess the meaning after several seconds. Engaging students in cracking some unfamiliar vocabularies is one of the most important aspects of critical literacy. Thus, the teacher and the students demonstrated how to crack the codes as seen in Excerpt 1.

At the second stage, students were told to disclose basic information about narrative stories when students tried to identify the generic structure of the narrative texts. In the classroom, the teacher adopted some strategies to assist students, such as providing a text poster, a story map, and a video of the story which 
aimed to encourage the students to crack the code pertaining to the basic information of the narrative text. The teacher also adapted some questions such as (1) what kind of text is this? (2) who wrote the text? and (3) what is the text about? (Luke \& Freebody, 1999).

In an attempt to identify the topic of the text, one student, Adnan (A), recognized that the nature of friendship embedded in the story of The Bear and the Two Friends, was delicate involving betrayal between good friends as shown in Excerpt 2 below.

\section{Excerpt 2}

T: Anyone knows what this story is about?

A: The story is about friendship

$\mathrm{T}$ : What's going on in their friendship?

A: Their friendship is fragile Miss

T: Very good, Adnan. What do you mean by fragile?

A: Uhm...ya itu miss ada masalah jadi yang satu ditinggalin yang satu bingung roti nya dimakan temennya [well, there's a problem, one person leaves the other one, and the other one is confused because the bread was eaten by his friend]

From this excerpt, Adnan tried to reveal the topic of the story by highlighting an event in the story where he believed that the friendship was "fragile." The strategy that the teacher used here seemed to work as the teacher probed more questions so that the student tried to break the code of a word that he said. In his response, Adnan tried to recall an event in the story to support his understanding of the word "fragile" that he mentioned earlier.

Another strategy that the teacher used to assist students in identifying the generic structure of the story was the use of a story map. The teacher distributed the story map to small groups of students and asked them to discuss the elements in each of the section.

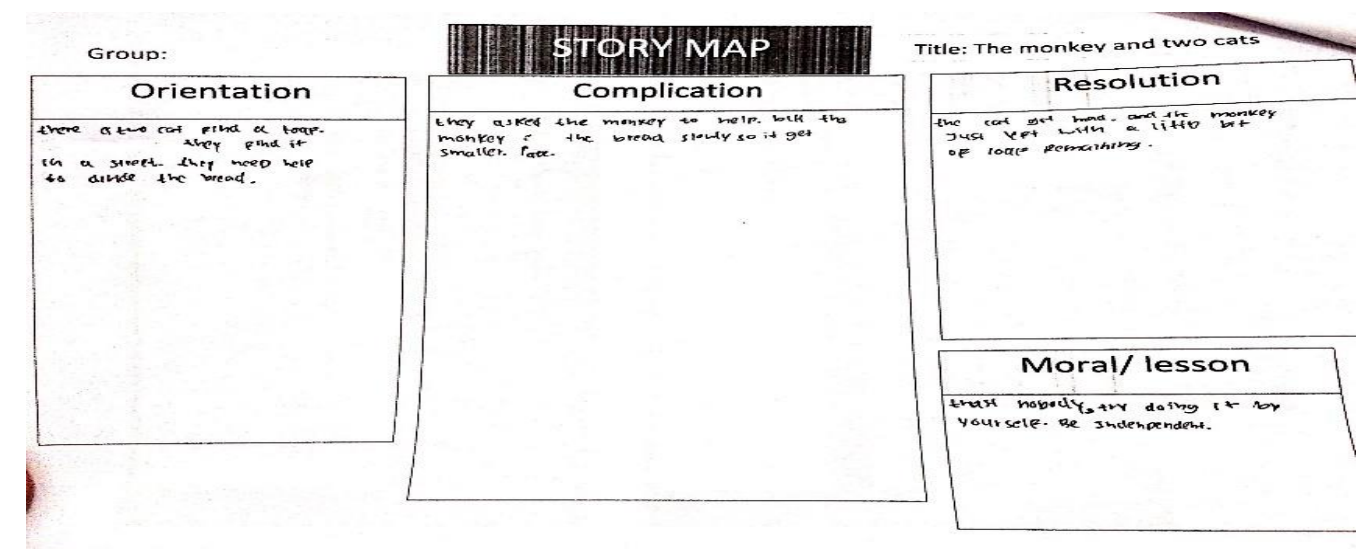

Figure 1. The story map

One of the groups created this story map. The students demonstrated an effort to identify the generic structure of the story, The Monkey and Two Cats. In the story map, the students were asked to identify such moves as an orientation, a complication, and a resolution. In addition to this, they identified a moral lesson implicitly or explicitly in the story. Despite some inaccuracies in the English language they used, these student participants showed a good understanding of how a narrative story unfolds. For example, in the orientation, the students wrote (in verbatim) there a two cat find a loaf, they find it the street. they need help to divide the bread. Students in this group seemed to gain a good understanding that the orientation sets the scene and mood as well as introduce characters. This move orients the reader to what will happen in the story. In the complication, students wrote the following statement: They asked the monkey to help (illegible) the monkey the bread slowly so it gets smaller (illegible). Here, the students tried to explain a sequence of the story when a problem arises. Meanwhile in resolution, the students wrote these: The cat got mad. and the monkey just left with a little bit of loaf remaining. They seemed to understand that the resolution is how the problem is solved at the end. Finally, in the moral lesson, students concluded trust nobody. try doing it by yourself. Be independent. From this story map that the teacher distributed, it seemed that some students recognized the structure of a narrative text as they tried to locate three different moves. In the beginning, the teacher did not try to correct students' writing, but instead the teacher celebrated the way students expressed their ideas accordingly.

The third code-breaking stage that the teacher practiced in the class was the visual code. The visual code included the characters and setting of the narrative texts. One of the students, Litta, was able to correctly guess the characters' personality and physical appearance in the story of Two Friends and the Bear. Litta could recognize two characters in the story, Chubby and Skinny, who have two different body sizes by the names that the teacher assigned. Litta further said that "you don't have to read the story until finish to guess that Chubby is fat while Skinny is a slim figure." This may indicate that Litta was able to visualize two distinct characters from the names.

The fourth code was breaking some non-verbal codes. It consists of such gestural aspects as characters' facial expressions and body language (Sandretto \& Tilson, 2013). To help students break the non-verbal 
codes, the teacher used some videos of the narrative stories that could improve students' literacy ability (Skouge, Rao, \& Boisvert, 2007). By watching the videos of the narrative stories, the students could imagine and understand the narrative texts. In the story of The Ugly Duckling, one of the participants, Mara, was able to identify the facial expressions and gestural aspects from the character of the ugly duckling. In the video, the ugly duckling's looked upset because he felt different from his family. From that non-verbal code, Mara believed that the ugly duckling felt different and thus made the ugly duck lose its confidence.

From the discussion above, the teacher used different strategies to help students engage in the first stage of breaking the code through the discussion on vocabulary, the structure of narrative texts, and visual and verbal codes. As students had now improved their basic knowledge about the narrative texts, the students proceeded to the next stage of making meaning of the texts.

\section{Participating in meaning making}

Within a critical literacy framework, meaning making of text involves activating students' prior knowledge which includes their social and cultural background and comparing their experiences with those described in the text (Tungka, 2018; Widodo, 2016a).

In the story of The Ugly Duckling, one participant shared a similar experience that happened to him as reflected by a character in the story. The student, Thariq, recalled that once he received unfair treatment from his friends at school because he was "different." He said that during his primary years, he had a stuttering problem that made it difficult for him to talk like other friends as seen in the interview excerpt.

\section{Interview Excerpt}

When we discussed The Ugly Duckling in the class, I had a similar experience when people around me think I'm different. In the past, I couldn't speak like this, I was different. And my friends treated me differently because the way I speak was weird for them (Thariq).

Thariq further said that being treated differently was not "a nice thing" to remember as it may lower one's self-esteem as what happened to the ugly duck in the story, and to him as well. Thariq also highlighted this particular experience in the classroom discussion, raising awareness of treating others fairly. The teacher seized this opportunity to teach students the core of critical literacy education: creating social justice (Lewison, Leland, \& Harste, 2015). At this stage, the teacher encouraged students to think about other circumstances where they experience or witness injustice as a result of being different. In the beginning, students seemed hesitant to talk; the teacher asked students what to do when they have a disagreement with their friends over something, or having different opinions with their siblings at home. Most participants reported that we have to respect people who are different. This important finding showed that students at all levels could be encouraged to broaden and develop social awareness, and critical literacy may be one of the strategies to help them.

The next stage is to use text functionally with the focus of understanding the purpose of the text and sociocultural background that underlies and influences how the text is shaped or constructed.

\section{Using text functionally}

In this phase, the students were expected to have a better understanding of the reasons why the text is written, explore particular genres, and recognize the cultural and social norms in the narrative texts (Luke and Freebody, 1999). Moreover, this stage was also identical to pragmatic practices since the students were encouraged to read contexts and assess how the technical features of the narrative texts (Luke, 2000). In achieving the goal of being a "text user" to use text functionally, students should understand the purposes of the text, recognize the options and alternatives for using a text to convey particular meaning effectively, realize that each text type has particular structures and features, and know what to do with a text in a particular context and what others might do with it (Ludwig, 2003).

During classroom discussions, most of the participants were able to identify the purpose and recognise the particular structure of the text they discussed. They realized that one of the purposes of narrative texts is to teach moral values through a series of events. The moral value from The Father, The Son, and The Donkey, for example, was that it is impossible to please everyone as showed as expressed by Dita "I learnt that we cannot make everyone happy because humans also have limitations. Not everyone who needs our help should be helped." Dita may have realized the beliefs and values embedded in the text as she participated in using the text functionally.

The last stage is becoming a text analyst through critically analyzing and transforming text.

\section{Analyzing text critically}

The last learning circle of helping students to become critically literate is analyzing and transforming text in order to take a critical stance on several issues and values presented in the narrative texts (Temple, 2005). Moreover, at this stage, students can be referred to as a text analyst since they represent their viewpoints and influence or convince other students (Duncan-Andrade \& Morrell, 2005). This text analyst stage focuses on recognizing the writer, speaker, or shaper's purpose of creating text and that text influences people's ideas/perspectives; identifying the ways in which information or ideas and expressed and represented to influence and position readers, viewers, or listeners; and recognizing opinions, biases, viewpoints, and gaps, which may be silent and dominant (Ludwig, 2003).

In order to become a text analyst, students were encouraged to take their stance on whether they agree or disagree with the issues and values presented in the narrative stories. One of the students, Hanung, 
responded to the story of The Father, The Son, and The Donkey. He questioned the father's preference for listening to whatever people say about him, his son, and his donkey. Hanung suggested that the father should have just focused on his son instead of trying to please everyone. Further, in the story of The Rabbit and The Turtle, Hanung also questioned why the rabbit slept during the race. He said the rabbit should have enough energy to prepare himself for the race. Hanung's decision to problematize the text may have indicated his understanding that texts are always written with certain purposes and that they may influence and position readers or listeners in certain ways.

At this stage, the teacher also challenged ordinary perspectives and dominant voices and thus encouraged students to write their own story to prove that texts may have been written in different ways and thus take a different position as readers. In The Father, The Son, and The Donkey, the following stories were written by two groups of students.

The first version of The Father, The Son, and The Donkey

Near a village, there were lived poor family. They were very confused and hadn't eat any food for days. So, they started to think to sell the donkey to buy some foods.

Then, they walked to the nearest butcher in the village. The butcher had a great deal with the donkey. So, they had a choice but to sell it. After they sold the donkey, they headed to a restaurant. They were too excited to eat and said to the waiter "give me your specialty". So the chef prepared the food and gave it to them. Once they tasted it, they were satisfied and said, " what is it in the amazing food?" and the same butcher came out and said "it was your donkey". And they were shocked and leave with disappointed.

In the first version of the story, these students decided that the donkey should be given a significant part in the story regardless of the sad ending that the donkey experienced. This may indicate that students were able to find the missing voice from the text, in this case, the donkey. In the original story, the donkey seemed to give a burden to the father and the son; therefore, they decided to sell it. In the second version of the story, the ending was different.

The second version of The Father, The Son, and The Donkey

Once upon a time, there were donkey, the man, and the son. They were on the journey to Palestine. On the way, they met with a group of man that wanted to buy the donkey. The son agreed but the father didn't agree. After that they argue each other, and the father gave up and sold the donkey. After they sold the donkey, they keep arguing. And they decided to separate each other.

In the second version of the story, the students decided that the father and the son should take their own journey because they believed that the son also deserved happiness. In the original story, the son was often blamed by people; the father did not stand behind him. In fact, the son was told to carry the father, as in the story that the donkey was unfair to the son. Therefore, students thought that the father and the son should be separated. Different from the first version in which the donkey was the highlight of the story; in the second version, characters were the father and the son.

The stories written by two groups of students may illustrate that texts tend to highlight certain voices; at the same time, silence other voices. By encouraging students to write their own story, the students were fully aware that texts could be written differently.

\section{CONCLUSION}

This article has presented empirical evidence on how the teacher adopted the four resources model of critical literacy in which students could reframe narrative stories from a critical literacy perspective. Throughout the critical reading process, the students played different roles as code breakers, text participants, text users, and text analysts. During this critical literacy-based language instruction, the students were reluctant to question or problematize the assigned texts in the beginning. They thought that story texts were neutral or apolitical. This suggests that engaging students in critical pedagogy is an urgent need for helping students become critical readers, for instance. Although the four resource models of critical literacy adopted in this study may be deemed insufficient (Serafini, 2012), in English language classrooms, this model is still relevant as it could guide both students and teachers to build a community of critical literacy in which students break, participate in, use, and critique texts.

\section{REFERENCES}

Duncan-Andrade, J. M. R., \& Morrell, E. (2005). Turn up that radio, teacher: Popular cultural pedagogy in new century urban schools. Journal of School Leadership,15(3), 284-304. doi: $10.1177 / 105268460501500304$.

Fajardo, M. (2016). Teaching critical literacy using multimodal texts to college students in the Philippines (Doctor of Education thesis). School of Education, University of Wollongong, Australia.

Green, B., \& Beavis, C. (Eds.). (2013). Literacy in 3D: An integrated perspective in theory and practice. Victoria, Australia: ACER Press. 
Gustine, G. (2018). A survey of critical literacy as a pedagogical approach to teaching English in Indonesia. Indonesian Journal of Applied Linguistics. 7(3), 531-537. doi: 10.17509/ijal.v7i3.9798

Huh, S. (2016). Instructional model of critical literacy in an EFL context: Balancing conventional and critical literacy. Critical Inquiry in Language Studies, 13, 210-235. doi: 10.1080/15427587.2016.1154445

Janks, H. (2014). Critical literacy’s ongoing importance for education. Journal of Adolescent and Adult Literacy. 57, 349-356. doi: 10.1002/jaal.260

Kim, S. (2016). Opening up spaces for early critical literacy: Korean kindergarteners exploring diversity through multicultural picture books. Australian Journal of Language and Literacy. 39(2), 176-187.

Ko, M.-Y. (2010). Critical literacy development in a college-level English reading class in Taiwan (Doctoral dissertation). Indiana University, Indiana, the USA.

Larson, J., \& Marsh, J. (2005). Making literacy real: Theories and practices for learning and teaching. New York: Sage.

Lewison, M., Leland, C., \& Harste, J. C. (2015). Creating critical classrooms: $K-8$ reading and writing with an edge. New York: Lawrence Erlbaum.

Ludwig, C. (2003). Making sense of literacy. Newsletter of the Australian Literacy Educators' Association, 1-4. Retrieved from https://www.alea.edu.au/documents/item/53\&sa=U $\&$ ei $=8 \mathrm{cJmU}$ -

LbJ4H40gWuqoDgDg\&ved=0CBsQFjAA\&usg= AFQjCNFryhhwKk690TUsxA7embdHD2sgbQ

Luke, A., \& Freebody, P. (1999). A map of possible practices: further notes on the four resources model. Practically Primary, 4(2), 5-8.

Luke, A. (2000). Critical literacy in Australia: A matter of context and standpoint. Journal of Adolescent \&
Adult Literacy, 43(5), 448-461.

Sandretto, S., \& Tilson, J. (2013). Reconceptualising literacy: Critical multiliteracies for "new times." Teaching and Learning Research Initiatives.

Retrieved from http://www.tlri.org.nz/sites/default/files/projects/S andretto_Summary_final_1.pdf

Serafini, F. (2012). Expanding the four resources model: Reading visual and multi-modal texts. Pedagogies: An International Journal, 7, 150-164. doi: 10.1080/1554480X.2012.656347

Skouge, J. R., Rao, K., \& Boisvert, P. C. (2007). Promoting early literacy for diverse learners using audio and video technology. Early Childhood Education Journal, 35(1), 5-11. doi: 10.1007/s10643-007-0170-y

Temple, C. (2005). Critical thinking and critical literacy. Thinking Classroom, 6(2), 15-20.

Tungka, N. F. (2018). Guided literacy instruction: Helping students read multimodal Englishmedium texts. Indonesian Journal of Applied Linguistics, 8, 345-357. doi: 10.17509/ijal.v8i2.13281

Widodo, H. P. (2016a). Engaging students in literature circles: Vocational English reading programs. The Asia-Pacific Education Researcher, 25, 347-359. doi: 10.1007/s40299-015-0269-7

Widodo, H. P. (2016b). Language policy in practice: Reframing the English language curriculum in the Indonesian secondary education sector. In R. Kirkpatrick (Eds.), English education policy in Asia (pp. 127-151). Cham, Switzerland: Springer.

Widodo, H. P. (2018). A critical micro-semiotic analysis of values depicted in the Indonesian Ministry of National Education-endorsed secondary school English textbook. In H. P. Widodo, L. V. Canh, M. R. G., Perfecto, \& A. Buripakdi (Eds.), Situating moral and cultural values in ELT materials: The Southeast Asian context (pp. 131-152). Cham, Switzerland: Springer. 